\title{
SAFETY CULTURE: THE INTERNATIONAL ASPECT
}

\section{Elviza Abiltarova}

Candidate of Pedagogical Sciences, Associate Professor, Institute of Vocational Education and Training of the National Academy of Pedagogical Sciences of Ukraine, Ukraine e-mail: elviza2008@gmail.com,orcid.org/0000-0001-9747-3303

\section{Adam Krzymowski}

Professor, Ph.D., Polonia University in Czestochowa, Interdisciplinary Faculty, Poland e-mail: akrzymowski@ap.edu.pl,orcid.org/0000-0001-9296-6387

\section{Summary}

The article provides a theoretical analysis of international documents regarding the origin and formation of the definition of "safety culture". It was found that the concept under study was first defined by the International Nuclear Safety Advisory Group of the International Atomic Energy Agency. The main international aspects of using the concept of "safety culture" are considered such as: organizational culture, harmonized safety culture. It was revealed that later the term "safety culture" began to appear in the documents of the International Labor Organization and was subsequently transformed into the culture of preventive measures in labor protection, the culture of occupational safety and health prevention. The work uses theoretical research methods such as: analysis, systematization and generalization of international documents, regulatory environment and scientific publications, classification, comparison, comparative analysis. It is concluded that it is necessary to conduct research related to the formation of safety culture among specialists in the field of occupational safety and health. The research results can be used as a theoretical basis for the development of conceptual provisions of safety culture formation.

Keywords: safety culture, International Labor Organization, occupational safety and health, training of specialists on occupational safety and health.

\section{DOI: https://doi.org/10.23856/4208}

\section{Introduction}

The problem of ensuring safety in the process of carrying out professional activities and sustainable development of society in the field of the conscious attitude to occupational safety and health issues takes an important stage in the current conditions and is a complex processes that requires comprehensive research. The study of the problem of safety culture, organizational culture of an enterprise, corporate culture, culture of life safety, since the $80 \mathrm{~s}$, has been of interest to both foreign (M. Griffin, D. Zohar, S. Cox, M. Cooper, J. Carroll, T. Lee, E. Neal, N. Pidgeon, P. Hudson) and domestic scientists (V. Akimov, E. Ayubov, T. Belykh, Y. Vorobiev, V. Gafner, I. Golubeva, L. Gorina, V. Devisilov, A. Dronov, R. Durnev, V. Evteev, T. Zyryanova, A. Kazmina, P. Kaigorodov, S. Kosynkina, A. Mikhailov, L. Mossoulina, V. Moshkin, I. Nemkova, V. Sapronov, A. Snegirev, T. Suvorova, N. Usachev). Furthermore, after the Chernobyl accident, issues related to the influence of the human factor on occupational safety, consideration of the psychophysiological causes of occupational injuries, including the psychological state of human health, erroneous actions of workers, unsafe deliberate actions of workers at the workplace, stress, depression, neuropsychic overload have become problem areas for many international organizations, 
especially in the operation of nuclear power plants. In view of the above, the designated aspects have determined the vector of research in the field of formation of safety culture on the part of the International Labor Organization and the International Atomic Energy Agency. The purpose of the article is to analyze the origin and formation of the definition of "safety culture" in international documents.

\section{Analysis of the IAEA Documents}

For the first time, the concept of "safety culture" was used in 1986 by the International Nuclear Safety Advisory Group (INSAG) of the International Atomic Energy Agency (IAEA) in the Summary Report on the Post-Accident Review Meeting on the Chernobyl Accident No. 75-INSAG-1 (1986). In this report, it was stated that the main reasons for the accident at the Chernobyl nuclear power plant are reasons of a professional and psychological nature: insufficient training of operating personnel (lack of knowledge about the physics of the reactor and the principles of its operation), negligence and laxity (admissibility of deviations from technical regulations on nuclear safety). It was these factors that revealed the level of safety culture at which the operating personnel violated a number of reactor operating rules and disabled the unit's protection systems.

In 1989, INSAG published its next report, Basic Safety Principles for Nuclear Power Plants, No. 75-INSAG-3, in which safety culture was described as a fundamental management principle. INSAG-3 (1989) stated that safety culture is linked to the personal responsibility and dedication of all those involved in any activity that affects the safety of nuclear power plants. The key element of safety culture is a focus on safe thinking that forms an internal critical position, excludes complacency and provides for the pursuit of excellence, the development of sense of personal responsibility and general self-regulation in safety matters. However, this document received a number of comments because the safety culture categories listed in it were vague and did not allow assessing its effectiveness.

Later in 1991, the Safety Culture report No. 75-INSAG-4 revealed the concept of safety culture and gave a clear definition of safety culture. Thus, the following formulation of safety culture was proposed: it is a set of characteristics and features of the activities of organizations and the behavior of individuals that establishes the nuclear power plant safety problems, as having the highest priority, are given attention determined by their importance. INSAG has established that, in its manifestation, safety culture has two main components. The scope of one is determined by the policies of organizations and the actions of leadership, while the other is manifested in the reactions of individuals working within this framework. In the opinion of INSAG, success depends on the commitment and competence defined by both components. In addition, INSAG recognizes that any correct procedures and good practice, if performed mechanically, are insufficient. Safety culture (INSAG-4, 1991) requires that all responsibilities important to safety are performed accurately, with care, meaningfully, based on full knowledge, common sense and responsibility. Sections 1-3 of the report reveal the requirements at the political level to the leaders of organizations and to individuals. In subsequent parts of the report, the tangible characteristics of satisfactory safety culture for different types of organizations are presented in more detail. Specifically, the main text does this in the form of statements on what to expect, and the addendum to the report does this in the form of questions presented to help organizations in self-monitoring.

In the next INSAG report No. 75-INSAG-7 "The Chernobyl Accident: Updating of INSAG-1" published in 1993 the reasons of the Chernobyl accident were clarified. In particular, 
it was emphasized that the design flaws of the reactor and elements of the control system contributed to human error occurrence.

Report No. 75-INSAG-12 "Basic Safety Principles for Nuclear Power Plants No. 75-INSAG-3 Rev.1" presents a revision of document No. 75-INSAG-3 issued in 1989, which formulated goals and principles for safe design and operation of nuclear power plants producing electrical energy. Revision No. 75-INSAG-12 was prepared with the aim of bringing the text in line with modern advances in the safety of nuclear power plants operation.

The safety culture report No. 75-INSAG-15 (2015) Key Practical Issues in Strengthening Safety Culture published in 2002 provides practical issues by which senior officials, managers and direct controllers of operating organizations would be able to evaluate the activity according to the established criteria. According to the chief specialist of the Central Institute for Advanced Studies of Rosatom State Corporation V.A. Mashin (2014), INSAG had to return to the "intangible" characteristics of safety culture, and once again try to translate them into "simple language" and formulate universal criteria for their assessment in practice.

In subsequent reports, the IAEA uses the term "organizational culture" as synonymous with safety culture. The accident at the Fukushima Daiichi nuclear power plant brought the issue of safety culture back to the first stage of relevance, and attention was drawn to the fact that the combination of such factors of occupational injuries as human, technological and organizational factors, requires a comprehensive analysis and their interaction directly affects nuclear safety. In view of the above positions, in 2016 the IAEA held an international conference dedicated to the 30 Years of Safety Culture Exploring (Dixit, Morqant, 2016). And already in 2020, the IAEA has presented a model of Harmonized Safety Culture that outlines exemplary behaviors such as individual responsibility, responsibility for decision-making, effective communication, and trusting relationships, which should be characteristic of employees of any organization promoting healthy safety culture (Chtzis, 2020).

The analysis of the international documents of INSAG shows that after the Chernobyl accident at the nuclear power plant, there was an increased interest of researchers in the issue of safety culture, but after the lapse of time, the study of this issue passed into a stage of uncertainty. Information data show a high level of discussion of the issue, at the same time the criteria for assessing safety culture have not been specified. We believe that the new challenges faced by humanity in 2011 after the accident at the Fukushima-1 nuclear power plant require an intensified and in-depth study of the problem associated with the psychophysiological causes of occupational injuries and the formation of safety culture among workers serving high-risk facilities.

Thus, based on the published reports, one can observe the development of the interest of INSAG in safety culture. It should be noted that the documents prepared by INSAG relate to the issues of ensuring the safety culture of nuclear power plants.

\section{Safety Culture in the ILO Documents}

It is well known that the ILO annually celebrates World Day for Safety and Health at Work on April 28 to commemorate workers killed and injured at work. Since 2003, the ILO has been using this day to promote and support the concept of an occupational safety and health culture. Thus, in June 2003, the International Labor Conference proposed Global Strategy on Occupational Safety and Health Conclusions, the main goal of which was to promote "culture of preventive measures on occupational safety and health". In subsequent reports (The ILO report, 2004, 2005) further study of the indicated problem was carried out. 
To follow up on the discussions considered in previous reports, the Promotional Framework for Occupational Safety and Health Convention (No. 187) was adopted in 2006 and defines the framework for the continuous promotion of culture of prevention in the field of occupational safety and health including methods such as public awareness, and actual knowledge of the dangers and risks starting from primary school age and throughout the work life.

In addition, for the implementation of the Convention, in 2006 Promotional Framework for Occupational Safety and Health Recommendation (No. 197) was developed to propose measures for increasing workers' awareness and understanding of the need to comply with requirements on occupational health and safety. A summary and systematization of the adopted provisions of Convention No. 187 and Recommendations No. 197 was presented in the 2007 report, the central theme of which was "Safe and Healthy Workplaces - Making Decent Work a Reality" (The ILO report, 2007).

It should be noted that in recent decades in European countries standards for quality management, occupational safety and health management systems started to operate, and the Zero Injury Programs began to be implemented, the norms of which are aimed at determining occupational risks and preventing occupational injuries. The ILO in its reports (The ILO report, 2015, 2016) also focuses on the importance of identifying occupational risks and hazards, calls on the national level to increase and maintain the culture of prevention in occupational safety and health.

Based on the analysis of international documents, we can observe the transformation of the concept of "safety culture" into the definitions of "labor protection culture", "culture of preventive measures in occupational safety and health", "culture of prevention in occupational safety and health". Generalization and systematization of scientific and pedagogical literature, dissertations, and scientific publications shows that in the Russian Federation the term "culture of life safety" is used very widely. It should be noted that the unifying factor in the above phrases is culture as a certain level of upbringing and education of a person. The second unifying factor is the psychological side of the issue that implies that employees have a conscious understanding and responsible attitude to labor safety.

\section{Conclusions}

Thus, the analysis of international documents and scientific information shows that the concept of "security culture" is widely discussed among international organizations and is multifaceted. In addition, it should be noted that the definition used is of key importance in ensuring safe and harmless working conditions at the workplace, as well as in the prevention of industrial injuries and occupational diseases, which is very important for the preservation of the life and health of workers. Therefore, we can conclude that the focus of our scientific work related to the formation of safety culture of future specialists in occupational health and safety has the correct direction vector, and requires increased and further attention to the considered aspect of research.

\section{References}

Mezhdunarodnaya organizaciya truda (2016) Formirovanie kul'tury ohrany truda [Building a preventive safety and health culture], Geneva: Mezhdunarodnaya organizaciya truda. Retrieved from: http://www.ilo.org/global/standards/subjects-covered-by-international-labour-standards/occupational-safety-and-health/WCMS_525546/lang--ru/index.htm

Chatzis I. (2020). IAEA Issues Harmonized Model for Enhanced Safety Culture in Nuclear Organizations. Vienna: IAEA Office of Public Information and Communication. Retrieved from: 
https://www.iaea.org/newscenter/news/iaea-issues-harmonized-model-for-enhanced-safety-culture-in-nuclear-organizations

Dixit A., Morgart R. (2016). Exploring 30 Years of Safety Culture: IAEA Hosts International Conference on Human and Organizational Aspects of Assuring Nuclear Safety. Vienna: IAEA Office of Public Information and Communication, IAEA Department of Nuclear Safety and Security. Retrieved from: https://www.iaea.org/newscenter/news/exploring-30-years-of-safety-culture-iaea-hosts-international-conference-on-human-and-organizational-aspects-of-assuring-nuclear-safety

Global Strategy on Occupational Safety and Health (2003) Conclusions adopted by the International Labour Conference at its 91st Session. International Labour Office. Retrieved from: http://www.ilo.org/wcmsp5/groups/public/---ed_protect/---protrav/---safework/documents/policy/wcms_107535.pdf

75-INSA $\bar{G}$-l (1986) Summary Report on the Post-Accident Review Meeting on the Chernobyl Accident. Vienna: International Atomic Energy Agency [in English].

75-INSAG-3 (1989) Basic Safety Principles for Nuclear Power Plants. Vienna: International Atomic Energy Agency [in English]

75-INSAG-4 (1991) Safety culture. Vienna: International Atomic Energy Agency [in English]

INSAG-7 (1993) The Chernobyl Accident: Updating of INSAG-1. Vienna: International Atomic Energy Agency [in English]

INSAG-12 (2015) Basic Safety Principles for Nuclear Power Plants 75-INSAG-3 Rev. 1. Vienna: International Atomic Energy Agency [in English]

INSAG-15 (2015) Key Practical Issues in Strengthening Safety Culture. Vienna: International Atomic Energy Agency [in English]

Mezhdunarodnaya organizaciya truda (2015) Vmeste povysim kul tury profilaktiki v ohrane truda [Join us in building a culture of prevention on OSH], Geneva: Mezhdunarodnaya organizaciya truda. Retrieved from: http://www.ilo.org/global/docs/WCMS_405838/lang--en/index.htm

Mashin V.A. (2014) Sovremennye osnovy koncepcii kul'tury bezopasnosti [Modern Basics of the Safety Culture Concept]. Elektricheskie stancii. Moscow: Nauchno-tekhnicheskaya firma "Energoprogress". Retrieved from: https://elibrary.ru/item.asp?id=22459708

International Labor Office (2004) A Promotional Framework for Occupational Safety and Health. Report 93 IV (1), Geneva: International Labor Office. Retrieved from: http://www.ilo. org/public/english/protection/safework/promoframe.htm

International Labor Office (2005) Prodvizhenie kul'tury ohrany truda. Doklad MOT $k$ Vsemirnomu dnyu ohrany truda [Promoting Safety and Health at Work. ILO Report for World Day for Safety and Health at Work], Geneva: International Labor Office. Retrieved from: http:// www.ilo.org/moscow/information-resources/publications/WCMS_312121/lang--ru/index.htm International Labor Office (2006) Konvenciya «Ob osnovah, sodejstvuyushchih bezopasnosti $i$ gigiene truda» [Promotional Framework for Occupational Safety and Health Convention], No. 187. Geneva: International Labor Office. Retrieved from: http://docs.cntd.ru/document/902237545

International Labor Office (2006) Rekomendaciya Mezhdunarodnoj organizacii truda «Ob osnovah, sodejstvuyushchih bezopasnosti i gigiene truda» [Promotional Framework for Occupational Safety and Health Recommendation], No. 197. Geneva: International Labor Office. Retrieved from: http://www.conventions.ru/view_base.php?id=627

International Labour Office (2007) Safe and Healthy Workplaces - Making Decent Work a Reality. The ILO Report for World Day for Safety and Health at Work. Geneva: International Labour Office. Retrieved from: https://www.ilo.org/safework/WCMS_108600/lang--en/index.htm 